Acta Universitatis Nicolai Copernici • Pedagogika XXXIV/2/2017

Nauki Humanistyczno-Społeczne • Zeszyt 440

DOI: http://dx.doi.org/10.12775/AUNC_PED.2016.027

Renata Deka

Uniwersytet Mikołaja Kopernika w Toruniu

\title{
Sprawozdanie z Ogólnopolskiej Konferencji Naukowej \\ Praca socjalna $w$ środowisku zamieszkania \\ i w szkole. W poszukiwaniu nowych sposobów rozwiqzywania problemów społecznych
}

(TORUŃ, 02.12.2016 R.)

$\mathrm{D}$

nia 2 grudnia 2016 r. odbyła się Ogólnopolska konferencja naukowa pt. Praca socjalna $w$ środowisku zamieszkania i $w$ szkole. W poszukiwaniu nowych sposobów rozwiązywania problemów społecznych. Na miejsce obrad konferencji wybrano Hotel Filmar. Organizatorami konferencji byli: Miasto Toruń, Miejski Ośrodek Pomocy Rodzinie w Toruniu, Fundacja Pro Europa oraz Katedra Pracy Socjalnej Wydziału Nauk Pedagogicznych Uniwersytetu Mikołaja Kopernika w Toruniu. Komitetowi Organizacyjnemu przewodniczyła dr Katarzyna Kuziak, pieczę organizacyjną sprawowały natomiast mgr Karolina Kramkowska, mgr Renata Deka, mgr Dagmara Wojciechowska oraz mgr Teresa Rożankowska. Do Komitetu Naukowego zaproszono z kolei: ks. dr. hab. Piotra Krakowiaka, który pełnił jednocześnie funkcję przewodniczącego, ks. dr. hab. Czesława Kustrę, prof. UMK, dr. hab. Tomasza Biernata, prof. WSB w Gdańsku, dr. Jana A. Malinowskiego, dr. Katarzynę Wasilewską-Ostrowską oraz dr. Jarosława Przeperskiego. Obrady konferencyjne zostały podzielone na dwie części (znalazło się w nich odpowiednio 5 i 6 wystąpień), a prelegenci reprezentowa- 
li pięć ośrodków naukowych: Uniwersytet Mikołaja Kopernika w Toruniu (Krakowiak, Malinowski, Wasilewska-Ostrowska, Kuziak, Przeperski), Uniwersytet im. Adama Mickiewicza w Poznaniu (Dobroniega Trawkowska), Wyższą Szkołę Bankową w Gdańsku (Biernat), Kujawską Szkołę Wyższą we Włocławku (Urszula Kempińska) oraz Uniwersytet Kazimierza Wielkiego w Bydgoszczy (Jolanta Jarczyńska, Karolina Kramkowska).

Obrady konferencyjne rozpoczęły się od powitania zgromadzonych na sali gości przez: Andrzeja Rakowicza - zastępcę Prezydenta Miasta Torunia, ks. dr. hab. Czesława Kustrę, prof. UMK, kierownika Katedry Pracy Socjalnej - ks. dr. hab. Piotra Krakowiaka, który odczytał także list od dziekana Wydziału Nauk Pedagogicznych dr. hab. Piotra Petrykowskiego, prof. UMK, oraz dyrektora Miejskiego Ośrodka Pomocy Rodzinie w Toruniu - mgr. Jarosława Bochenka. Po zakończeniu oficjalnego przywitania gości rozpoczęła się pierwsza część obrad, której moderatorami byli ks. dr hab. Piotr Krakowiak oraz dr Jan A. Malinowski. W tej części goście mieli okazję wysłuchać m.in. referatu mgr. Jarosława Bochenka Praca socjalna $-w$ kontakcie ze szkoła. W perspektywie doświadczeń ośrodka pomocy społecznej oraz ks. dr. hab. Krakowiaka, który w wystąpieniu pt. Praca socjalna $w$ środowisku zamieszkania $i$ w szkole - inspiracje z wybranych dobrych praktyk europejskich przedstawił szkocki program named person, prezentując założenia oraz zagrożenia wynikające z tegoż projektu. Kolejnymi ciekawymi wykładami były prelekcje pt. Praca socjalna z rodzi$n a$ w środowisku zamieszkania - stan i perspektywy dr hab. Dobroniegi Trawkowskiej, prof. UAM, oraz Grupy wsparcia dla rodzin jako forma środowiskowej pracy socjalnej dr. hab. Tomasza Biernata, prof. WSB w Gdańsku. Ostatnim wystąpieniem w pierwszej części obrad był referat dr Urszuli Kempińskiej z KSW we Włocławku zatytułowany Praca socjalna z nieletnimi matkami, która zaprezentowała systemy wsparcia młodych nieletnich matek w wybranych państwach Europy, m.in. we Francji i Anglii, zestawiając je jednocześnie z ofertą polskiego systemu.

Po przerwie kawowej swoje wykłady wygłosili m.in. dr Jolanta Jarczyńska z Uniwersytetu Kazimierza Wielkiego w Bydgoszczy i mgr Tomasz Jurkiewicz, kierownik Miejskiego Schroniska dla Bezdomnych Mężczyzn w Toruniu - Rozwój empowermentu u pedagogów i pracow- 
ników socjalnych oraz beneficjentów na polu zagrożeń dla młodzie$\dot{z} y$ i wykluczenia społecznego, będący owocem projektu realizowanego w ramach programu Erasmus+, a następnie dr Malinowski: Szkoła w obszarze zainteresowania pracy socjalnej. W dalszej części uczestnicy konferencji mieli okazję wysłuchać dr. Jarosława Przeperskiego w wystąpieniu Nowe paradygmaty $w$ obszarze wsparcia rodziny $w$ środowisku lokalnym oraz dr Katarzyny Wasilewskiej-Ostrowskiej w referacie Dzieci ulicy wyzwaniem dla pracy socjalnej, która zaprezentowała wyniki badań prowadzonych przez streetworkerów na toruńskich ulicach. Kolejnym ciekawym referatem była prelekcja dr Katarzyny Kuziak pt. Inicjatywy oddolne na rzecz pracy socjalnej $w$ środowisku lokalnym. Ostatnim wykładem, zamykającym część plenarną, było wystąpienie mgr Karoliny Kramkowskiej, która przedstawiła wykład zatytułowany Edukacja dzieci $w$ zakresie problemu demencji $w$ rodzinie $i$ środowisku lokalnym, przybliżając skalę problemu, jakim jest demencja oraz pokazując, w jaki sposób można na ten temat rozmawiać z dzieckiem doświadczającym choroby jednego z członków swojej rodziny.

Zakończeniem konferencji było podsumowanie podjętych rozważań. Na kanwie zaprezentowanych referatów wytworzyła się w dyskusja, w której czynny udział wzięli licznie zgromadzeni na sali praktycy - pracownicy socjalni z Torunia i ościennych miejscowości. W czasie dyskusji poczyniono także plany odnośnie do kolejnej edycji konferencji i jej ewentualnego kształtu.

Zaprezentowane w czasie obrad konferencyjnych wystąpienia stały na wysokim poziomie i obejmowały szerokie spektrum zagadnień, dzięki czemu spełniły oczekiwania gości zgromadzonych na sali obrad. Wydaje się jednak, że przy planowaniu ewentualnej przyszłej konferencji warto wziąć pod uwagę zmianę lokalizacji konferencji i przenieść obrady w mury uczelni, co umożliwiłoby udział w nich także studentom zainteresowanym problematyką. Oczywiście jest to tylko sugestia, która nie umniejsza w żaden sposób sukcesu Ogólnopolskiej konferencji naukowej Praca socjalna $w$ środowisku zamieszkania i $w$ szkole. W poszukiwaniu nowych sposobów rozwiązywania problemów społecznych, zdaje się jednak dawać szansę jej dalszego rozwoju. 
